\title{
Survey Pemanfaatan Medicinal Herbs untuk Peningkatan Produktivitas dan Kesehatan Ternak Ruminansia di Bengkulu
}

\section{The Use of Medicinal Herbs for Improving Productivity and Ruminant Health in Bengkulu}

\author{
T. Suteky, Dwatmadji, dan E. Sutrisno \\ ${ }^{1}$ Department of Animal Science, Faculty of Agriculture, University of Bengkulu. \\ Address: Jalan WR Supratman, Kandanglimun, Bengkulu. 38371. INDONESIA. \\ Corresponding Author: Dwatmadji.2008@gmail
}

\begin{abstract}
The study was conducted to find out the local medicinal herbs used to treat livestock disease and to increase livestock production. Data were obtained using questionnaires from 75 small farmers practicing medicinal herbs for their livestock in three areas of Bengkulu. The information collected from the respondents included local name, use, part of herbs used, preparation and route of administration as well as other ingripeletnts added. Our findings showed that a total of 33 medicinal herb species belonging to 14 families were documented. The most common herbs used belonged to family Zingiberaceae which contained 7 species herbs, while the others were represented by one species in each family. Our findings also showed that Curcuma longa Linn or Curcuma domestica the commonly utilized herb for appetite inducement, disease prevention, bloat, helminthiasis, and lesion/wound. Rhizomes were majority parts of medicinal herbs used followed by leaves and seeds. Oral administration was the frequent application of medicinal herbs, come after by topical. The sceintific name and phytochemical compounds were stupeletd based on the literature reviewed. Medicinal herbs commonly used by farmer were kitchen herbs, therefore they were relatively safe for ruminants.
\end{abstract}

Key words: herbs, production, health, ruminats

\begin{abstract}
ABSTRAK
Penelitian ini bertujuan untuk mendokumentasikan tanaman obat lokal yang dipergunakan untuk peningkatan produktivitas dan kesehatan ternak ruminansia di Bengkulu. Data diperoleh melalui wawancara terhadap 75 petani di Bengkulu, semi stuktur quisioner dipergunakan sebagai pedoman untuk bertanya seperti nama tanaman yang dipergunakan, bagian yang dimanfaatkan, cara penggunaannya, dan termasuk bahan lain yang ditambahkan. Setiap tumbuhan yang disebut oleh responden dicatat nama lokal untuk identifikasi nama ilmiahnya. Pada penelitian ini studi literatur dipergunakan untuk mengetahui nama ilmiah/latin dan untuk mengetahui kandungan fitokimianya. Data dianalisis secara deskripstif. Hasil penelitian menunjukkan tercatat ada 33 medicinal herbs yang dipakai oleh petani peternak, tanaman tersebut masuk dalam 16 genus dan 14 famili. Medicinal herbs dari famili Zingiberaceae yang terdiri dari 7 species merupakan tanaman yang paling banyak dimanfaatkan, sedangkan 13 famili yang lain diwakili 1 species setiap familinya. Curcuma longa Linn dan Curcuma domestica merupakan medicinal herbs yang paling banyak dipergunakan untuk meningkatkan nafsu makan, mencegah penyakit, bloat, infestasi parasit internal, dan luka. Pemberian tanaman obat secara per oral merupakan metode yang paling banyak dipergunakan diikuti dengan cara topikal. Nama ilmiah dan komponen fitokimia dipelajari berdasarkan studi literatur. Medicinal herbs yang dipergunakan oleh petani peternak kebanyakan merupakan kitchen herbs dengan demikian tanaman ini relatif aman untuk ternak ruminansia.
\end{abstract}

Kata kunci: herbal, produksi, kesehatan, ruminansia

\section{PENDAHULUAN}

Pengembangan ternak ruminansia terutama sapi potong ditentukan oleh berbagai faktor antara lain produktivitas dan kesehatan ternaknya. Pendekatan aspek sosial budaya seperti pemanfaatan herbal oleh peternak bisa menjadi salah satu faktor penting dalam usaha pengembangan ternak sapi. Setidaknya $80 \%$ penduduk di negara berkembang menggantungkan pada pengetahuan lokal untuk mencegah dan mengobati penyakit ternak dan penyakit pada manusia (Jabbar et al., 2005). India and China terkenal memiliki kekayaan pengetahuan lokal tentang pemanfaatan herbal untuk kesehatan. Pengetahuan mereka 
telah menarik perusahaan farmasi untuk pengembangan obat modern melalui riset dan pengembangan untuk obat baru (WHO, 2008). Hal ini sejalan dengan visi WHO Traditional Medicine Strategy 2014- 2023 (WHO, 2013) mendorong penggunaan obat tradisional dalam sistem kesehatan nasional.

Bengkulu seperti daerah lain di Indonesia juga memiliki kekayaan tumbuhan/herbal yang berpotensi sebagai sumber obat-obatan (Suteky et al., 1998). Aghsaghali (2012) menyatakan bahwa medicinal herb dapat meningkatkan kecernaan, sebagai anti bakteri, anti oksidan, anti radang dan imuno stimulan.

Suteky et al. (2016) melaporkan bahwa penyakit yang sering menyerang ternak ruminansia adalah cacingan dengan angka infeksi mencapai $47,76 \%$, morbiditas 90\% dan tersebar di seluruh kecamatan di Kabupaten Bengkulu Selatan, mortalitas bisa mencapai 66,7-80\% (Suteky and Dwatmadji, 2011 dan 2016) tergantung tingkat infestasinya. Penyakit lain yang sering menyerang sapi adalah Pink Eyes dengan angka infeksi sebesar 13,01\% (Suteky et al., 2016), penyakit ini dilaporkan sebagai penyebab kematian ternak kambing di daerah Kaur, Propinsi Bengkulu, pada bulan September 2019 (personal communication). Menurut Tariq et al. (2014) pada umumnya pengetahuan seseorang tentang pemanfaatan herbal untuk ternak biasanya ditularkan dari orang tua ke anaknya, tanpa ada dokumentasinya. Penelitian ini bertujuan untuk mendokumentasikan tanaman obat/herbal yang dipergunakan untuk peningkatan produktivitas dan kesehatan ternak ruminansia di Bengkulu.

\section{METODE PENELITIAN}

Penelitian dilakukan dari April sampai dengan Juni 2019 pada petani peternak dan kelompok ternak yang ada di 3 Kabupaten di Bengkulu yaitu Bengkulu Tengah, Kota Madya Bengkulu dan Kepahyang. Pemilihan lokasi dilakukan secara purposive, dengan pertimbangan bahwa lokasi tersebut merupakan lokasi pengembangan sapi. Data awal respoden didapatkan dari ketua kelompok ternak desa Srikaton (Bengkulu tengah), kelompok ternak desa Tugu rejo (Kepahyang) dan atau tokoh masyarakat. Inteview dilakukan secara langsung terhadap 75 peternak terpilih, informasi yang dikumpulkan terkait dengan data responden, nama tanaman yang dipergunakan, bagian yang dimanfaatkan, cara penggunaannya, dan termasuk bahan lain yang ditambahkan. Setiap tumbuhan yang disebut oleh responden dicatat nama lokal untuk identifikasi nama latinnya. Pada penelitian ini studi literatur dipergunakan untuk mengetahui nama ilmiah/latin dan kandungan fitokimia. Data yang diperoleh ditabulasi dan dianalisis secara kualitatif (deskriptif).

\section{HASIL DAN PEMBAHASAN}

Karakteristik responden tertera pada Tabel 1, peternak didominasi oleh laki-laki, tingkat pendidikan paling banyak sampai level SD, peternak dengan umur dibawah 30 tahun sangat minim. Hal ini disebabkan karena anak-anak muda lebih menyukai bekerja diluar bidang petani/peternakan. Hampir $60 \%$ peternak memiliki 1-10 sapi dengan berbagai umur dan jenis kelamin, dan hanya $16 \%$ responden yang memiliki ternak lebih dari 20 ekor sapi.

Hasil penelitian menunjukkan bahwa ada 23 tumbuhan/herbal yang digunakan peternak untuk meningkatkan produktivitas dan kesehatan ternak nya. Diluar yang tertera pada Tabel 2 masih ada 10 herbal lain yang digunakan masing-masing oleh seorang peternak yakni tumbuhan Bangun-bangun (Coleus amboinicus) dan Kopi untuk mengatasi kembung, Moringa citrifolia dan Artocarpus heterophyllus untuk meningkatkan nafsu makan, randu, lengkuas dan gamal untuk demam, jeruk untuk penyakit mata, cabe untuk luka. 
Tabel 1. Data peternak responden

\begin{tabular}{cccc}
\hline Tingkat Pendidikan & $\%$ & Tingkat Pendidikan & $\%$ \\
\hline SD & 44 & Sarjana & 7 \\
SMP & 24 & S2 & 0 \\
SMA & 25 & & \\
Kepemilikan sapi (ekor) & & Kepemilikan sapi (ekor) & 25 \\
$1-5$ & 33 & $11-20$ & 16 \\
6-10 & 25 & $>21$ & 26,67 \\
Umur (tahun) & & Umur (tahun) & 12,0 \\
$\quad<30$ Tahun & 2,67 & $>51-60$ tahun \\
>30-40 Tahun & 24,0 & $>60$ & \\
$>41-50$ Tahun & 34,67 & &
\end{tabular}

Tabel 2. Nama herbal yang dipakai peternak, nama latin, famili, cara pemakaian, manfaat dan jumlah peternak yang memakai dari 75 responden/peternak.

\begin{tabular}{|c|c|c|c|c|c|c|c|}
\hline No & Nama Lokal & Nama latin & Family & $\begin{array}{l}\text { Bagian } \\
\text { dipakai }\end{array}$ & $\begin{array}{l}\text { Cara } \\
\text { pemakaian }\end{array}$ & Manfaat & $\begin{array}{l}\square \text { yang } \\
\text { memakai }\end{array}$ \\
\hline 1 & Kunyit & $\begin{array}{l}\text { Curcuma } \\
\text { domestica }\end{array}$ & $\begin{array}{l}\text { Zingiberac } \\
\text { eae }\end{array}$ & Rimpang & $\begin{array}{l}\text { Per os \& } \\
\text { kadang + } \\
\text { bawang } \\
\text { putih }\end{array}$ & $\begin{array}{l}\text { Meningkatkan nafsu } \\
\text { makan, kembung, } \\
\text { luka, cacingan dan } \\
\text { diare }\end{array}$ & 24 \\
\hline 2 & Pinang & $\begin{array}{l}\text { Leucaena } \\
\text { leucocephala }\end{array}$ & Arecaceae & Biji & Per os & Cacingan & 15 \\
\hline 3 & Jahe & $\begin{array}{l}\text { Zingiber } \\
\text { officiale }\end{array}$ & $\begin{array}{l}\text { Zingiberac } \\
\text { eae }\end{array}$ & Rimpang & Per os & $\begin{array}{l}\text { Meningkatkan nafsu } \\
\text { makan, kembung, } \\
\text { diare, pencegahan } \\
\text { penyakit }\end{array}$ & 14 \\
\hline 4 & Pepaya & Carica papaya & Caricaceae & Batang & Per anal & $\begin{array}{l}\text { Daun (meningkatkan } \\
\text { nafsu makan, } \\
\text { cacingan, mencegah } \\
\text { penyakit). Daun + } \\
\text { arang untuk diare, } \\
\text { batang untuk } \\
\text { kembung (per anal) }\end{array}$ & 10 \\
\hline 5 & Asam jawa & $\begin{array}{l}\text { Tamarindus } \\
\text { indica }\end{array}$ & Fabaceae & Buah & $\begin{array}{l}\text { Campur } \\
\text { dengan } \\
\text { kunyit } \\
\text { diminum }\end{array}$ & $\begin{array}{l}\text { Membantu } \\
\text { pencernaan, } \\
\text { kembung, cacingan, } \\
\text { demam }\end{array}$ & 7 \\
\hline 6 & $\begin{array}{l}\text { Bawang } \\
\text { merah }\end{array}$ & Allium cepa & $\begin{array}{l}\text { Amaryllida } \\
\text { ceae }\end{array}$ & Umbi & Topikal & $\begin{array}{l}\text { Pencegahan penyakit } \\
\text {, diare dan scabies, } \\
\text { kembung }\end{array}$ & 7 \\
\hline 7 & Temu hitam & $\begin{array}{l}\text { Curcuma } \\
\text { aeruginosa } \\
\text { Roxb }\end{array}$ & $\begin{array}{l}\text { Zingiberac } \\
\text { eae }\end{array}$ & Rimpang & Per os & $\begin{array}{l}\text { Kembung, } \\
\text { meningkatkan nafsu } \\
\text { makan }\end{array}$ & 7 \\
\hline 8 & Sereh & $\begin{array}{l}\text { Cymbopogon } \\
\text { citratus }\end{array}$ & Poaceae & Batang & $\begin{array}{l}\text { Dicampur } \\
\text { kencur dan } \\
\text { gula merah }\end{array}$ & $\begin{array}{l}\text { Meningkatkan } \\
\text { stamina ternak }\end{array}$ & 6 \\
\hline 9 & Jambu & $\begin{array}{l}\text { Psidium } \\
\text { guajava }\end{array}$ & Myrtaceae & Daun & Per os & $\begin{array}{l}\text { Pencegahan penyakit } \\
\text { dan Diare }\end{array}$ & 4 \\
\hline 10 & Cinto ali & $\begin{array}{l}\text { Tinospora } \\
\text { crispa }\end{array}$ & $\begin{array}{l}\text { Menisperm } \\
\text { aceae }\end{array}$ & Daun & $\begin{array}{l}\text { Dicampur } \\
\text { dengan } \\
\text { kunyit-per } \\
\text { os }\end{array}$ & $\begin{array}{l}\text { Meningkatkan } \\
\text { stamina ternak, luka, } \\
\text { cacingan }\end{array}$ & 3 \\
\hline
\end{tabular}




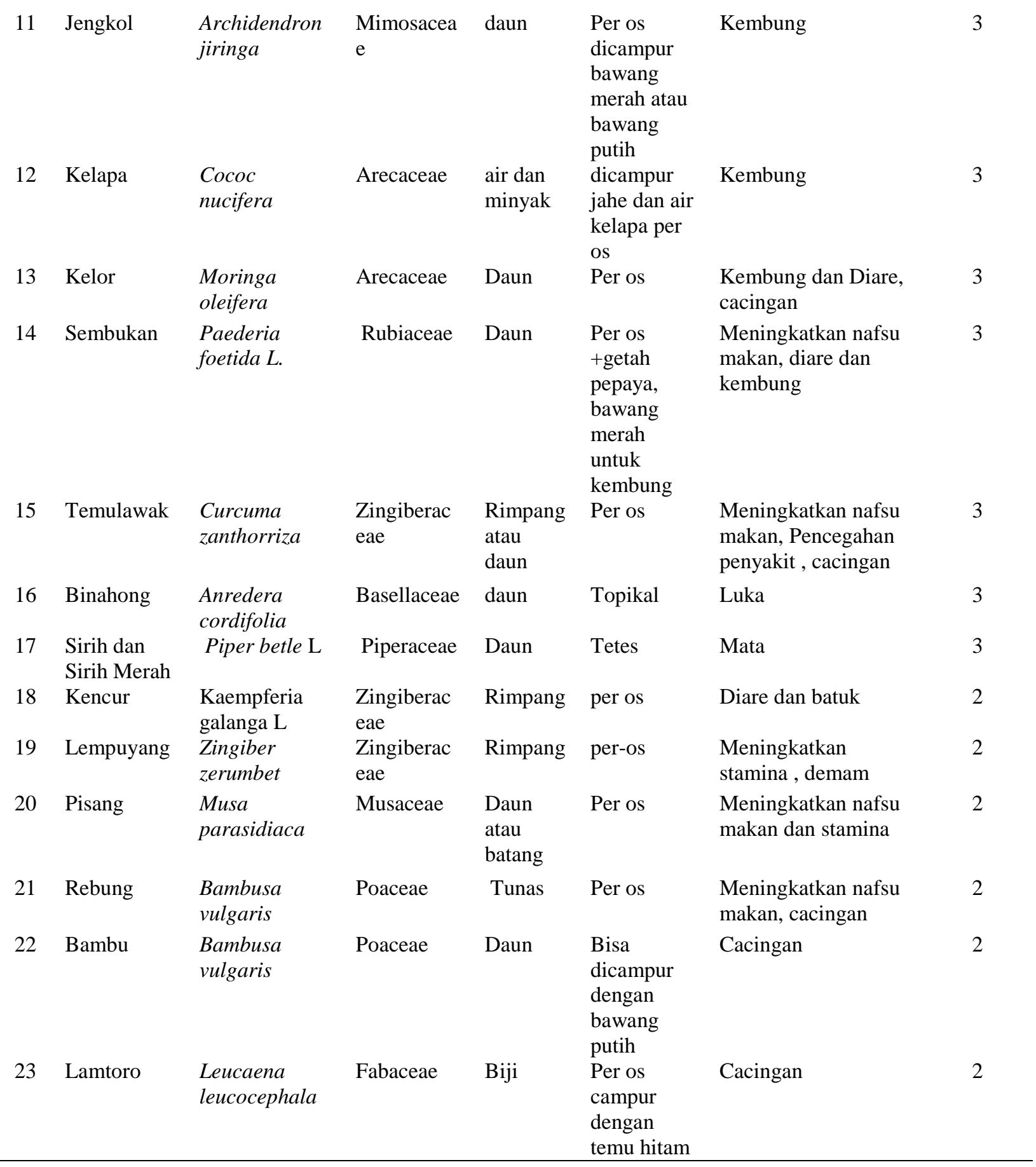

Kunyit merupakan herbal yang paling sering dimanfaatkan oleh peternak yakni sebesar 32\%. Ammon dan Wahl (1991) melaporkan bahwa pemanfaatan kurkumin yang berasal dari kunyit untuk pengobatan sudah dilakukan lebih dari 2000 tahun yang lalu dan masih dipakai sampai saat ini. Tabel 2 memperlihatkan bahwa peternak memakai kunyit untuk meningkatkan nafsu makan, mengatasi kembung, diare, dan cacingan. Penggunaan kunyit/curcuma untuk kembung juga dilaporkan oleh Ullah et al. (2015).
Curcumin secara luas telah dipakai sebagai anti oksidan, anti radang dan secara in vitro berkasiat sebagai anti tumor (Hatcher et al., 2008), anti coccidia (Cervantes-Valencia et al., 2015), meningkatkan performa ayam petelur (Frita et al., 2016), mastitis, luka dan bengkak pada leher, pendarahan pada tanduk (Phondani et al., 2010 ). Herbal ke dua yang banyak dipakai (15 peternak) adalah pinang sebagai obat cacing. Adanya zat aktif seperti alkaloids, tannins, flavones, triterpenes, steroids pada pinang telah 
terbukti menunjukkan aktivitas sebagai anti parasit, anti-depresi, anti oksidan, anti jamur, anti hipertensi, anti radang, dan dapat meningkatkan fungsi pencernaan (Peng et al., 2015).

Peternak menggunakan jahe untuk meningkatkan nafsu makan, menjaga stamina, pengobatan diare, dan kembung. Penggunaan jahe sebagai obat tradisional tidak hanya dipakai oleh masyarakat Indonesia, tapi juga di negara berkembang lainnya dan bahkan negara maju. Zat aktif yang terkandung pada jahe seperti gingerol, camphene, curcumin, alpha-zingiberene mampu menstimulasi sistem pencernaan sehingga meningkatkan absobsi pakan/makanan, mencegah kembung, melancarkan sirkulasi darah (Zadeh and Kor, 2014), memelihara fungsi rumen (Al-Azazi et al., 2018), meningkatkan efisiensi nitrogen dan jumlah protozoa rumen (Kurniawati et al., 2018).
Pepaya mengandung berbagai macam zat aktif, baik pada daun, buah, biji dan getahnya sehingga sangat potensial sebagai tanaman obat. Peternak menggunakan daun pepaya untuk meningkatkan nafsu makan, mencegah penyakit, dan obat cacing, peternak juga menggunakan pelepah pepaya untuk mengatasi kembung. Khrisna et al. (2008) menyatakan bahwa setiap bagian dari pepaya memiliki aktivitas pharmakologis sebagai anthelmentika, anti diare, jaundice, dispepsia, pendarahan, batuk, anti radang, anti bakteri, dan luka bakar. Menurut Dalimartha (2009) daun pepaya dapat meningkatkan nafsu makan. Ameen et al. (2010) menyatakan bahwa biji pepaya memiliki aktivitas anti nematoda pada domba. Namun sejauh ini belum ada bukti ilmiah tentang penggunaan pelepah pepaya untuk mengatasi kembung.

Tabel 3. Hasil studi pustaka pada zat aktif herbal yang paling sering dipakai peternak

\begin{tabular}{|c|c|c|}
\hline No & $\begin{array}{l}\text { Nama } \\
\text { Herbal }\end{array}$ & Zat aktif serta referensi yang diacu \\
\hline 1 & Kunyit & $\begin{array}{l}\text { Curcumin, Ar-turmerone, Bisdemethoxycurcumin, ar-turmerone , curcumenol, } \beta \text {-turmerone } \\
\text { (Jantan and Saputri, 2012). }\end{array}$ \\
\hline 2 & Pinang & $\begin{array}{l}\text { Alkaloids, tannins, flavones, triterpenes, steroids, and fatty acids.(Peng et al., 2015). } \\
\text { Catechin, tannins, alkaloid (Arecoline, arecaine, Arecaidine and guvacoline, guvacine and } \\
\text { choline), Joshi et al. (2012). }\end{array}$ \\
\hline 3 & Jahe & $\begin{array}{l}\text { Gingerol, Camphene, curcumin, alpha-zingiberene, b -bisabolene (Batht, 2015., Zadeh and } \\
\text { Kor, 2014) }\end{array}$ \\
\hline 4 & Pepaya & $\begin{array}{l}\text { Daun mengandung alkaloid carpain, pseudocarpain, choline, carposide vitamin C dan E } \\
\text { (Krishna, 2008). Getah pepaya asam aspartat, treonin, serin, asam glutamat, prolin, alanin, } \\
\text { valine, isoleusin, leusin, tirosin, fenilalanin, histidin, lisin, arginin, triptofan, dan sistein } \\
\text { (Prabantini, 2013). alkaloids, saponins, phytate, flavonoid, tannin and glycosides (Oche et } \\
\text { al., 2017., ) }\end{array}$ \\
\hline 5 & Asam jawa & $\begin{array}{l}\text { Tannins, saponins, sesquiterpenes, alkaloids, and phlobatamins (Doughari, 2006). Vitamins, } \\
\text { minerals, tartaric acid, acetic acid, citric acid,formic acid, malic acid, and succinic acid, } \\
\text { amino acids (Menezes et al., 2016), fatty acids, } \mathrm{Mg}, \mathrm{Mn}, \mathrm{Ca}, \mathrm{P}, \mathrm{Na}, \mathrm{Zn}, \mathrm{K}, \mathrm{Fe} \text { (Khanzada et } \\
\text { al., 2008). }\end{array}$ \\
\hline 6 & $\begin{array}{l}\text { Bawang } \\
\text { merah }\end{array}$ & $\begin{array}{l}\text { Sulfur amino acids, flavonoids and phytosterols, flavonols, anthocy- anin pigments, sterols } \\
\text { and saponins (Brewster, 1994) (g-glutamyl, systeines, alliin ( Bhatt., 2015). }\end{array}$ \\
\hline 7 & Temu hitam & $\begin{array}{l}\text { Zedoarol, curcumenol, isocurcumenol (Sukari et al., 2007) curzerenone 1,8-cineole camphor } \\
\text {, zedoarol, isocurcumenol curcumenol, and furanogermenone (Simoh and Zainal, 2015., } \\
\text { Sirat et al ., 1998.) }\end{array}$ \\
\hline 8 & Sirih & $\begin{array}{l}\text { Eugenol , asam 2,5-dimetilbenzoat, dekahidro-4a-metil-1-metilenyl naftalena, ., } \\
\text { 1,2,3,4,4a,5,6,8a-oktahidro-7-metil naftalena, dan 1,2,3,4, 4a,5,6,8a-oktahidro-4a- } \\
\text { metilnaftalena (Pratiwi dan Muderawan, 2016). }\end{array}$ \\
\hline
\end{tabular}


9 Daun Jambu Triterpenoid guajanoic acid $\beta$-sitosterol, uvaol, oleanolic acid and ursolic acid, globulol, tamarixetin , gossypetin ,quercetin, kaempferol, guajaverin, avicularin glucopyranoside , phydroxy-benzoic acid, guavinoside (Begum et al., 2004., Shao et al., 2014).

10 Air kelapa Vitamin C, asam folat, phytohormon (auxin, 3-diphennylure, cytokinin), enzym (phosphatase, catalase, dehydrogenase, diastase, peroxidase, RNA polymerase) (Yong et al., 2009), K, Na, $\mathrm{Ca}$, dan $\mathrm{Mg}$.

11 Brotowali Alkaloids, diterpenoid, lactones, glycosides, steroids, sesquiterpenoid, phenolics, aliphatic compounds and polysaccharides.(Singh et al., 2003).

12 Bawang Alliin, alliinase, allicin, S-allyl cysteine (SAC), diallyldisulphide (DADS), diallyltrisulphide putih (DATS) and methyl allyl trisulphide. The $\gamma$-glutamyl-S-alk(en)yl-L-cysteines (Divya et al., 2017).

13 Daun Flavan, proanthocyanidins, di-O-gallates, gallocatechin (Bunawan et al., 2013).

Jengkol

14 Kelor

4-(4'- $O$-acetyl-a-L-rhamnopyranosyloxy) benzyl isothiocyanate, niazimicin, pterygospermin, carotenoids 3 -O-(6'-O-oleoyl- $\quad \beta$-D-glucopyranosyl) $\quad-\beta$-sitosterol $\beta$-sitosterol-3-O- $\beta$-Dglucopyranoside (Anwar et al., 2007).

15 Daun Irridoid glycosides, methanethiol, triterpenoids, sterols, coumarins, phenolic acids, and Sembukan anthraquinones, carotene., a triterpene (ursolic acid)., steroids (sitosterol, stigmasterol, campesterol (Wang et al., 2014). alkaloids, flavonoids (Shaswat et al., 2018).

16 Binahong Flavanoid, saponin, tannins, alkaloids, polyphenols, triterpenoid, steroid ( Astuti et al., 2011., Garmana et al., 2014).

Asam jawa dipergunakan oleh beberapa peternak di Bengkulu untuk meningkatkan pencernaan, cacingan dan kembung. Asam merupakan tanaman yang memiliki banyak manfaat kesehatan seperti menyembuhkan luka, gigitan ular, sakit perut, diare, cacingan, demam, jaundice dan sebagai pembersih kulit (Menezes et al., 2016., Doughari, 2006). Peternak ada yang menambah kunyit pada asam jawa untuk mengobati kembung.

Bawang merah digunakan untuk mencegahan penyakit, diare, scabies, dan kembung. Phondani et al. (2010), menyatakan bahwa bawang merah dapat dipergunakan untuk mengatasi keracunan, disentri, dan penyakit mulut dan kuku. Kumar et al. (2010) melaporkan bahwa bawang merah memiliki banyak kasiat sebagai anthelmintika anti-radang, antiseptik, antispasmodik, karminatif, diuretik, expectorant, febrifuge dan lainnya.

Peternak menggunakan brotowali/cinto ali (Tinospora cordifolia) untuk meningkatkan stamina ternaknya. Gupta et al. (2016) membuktikan bahwa pemberian suplementasi pakan yang mengandung Tinospora cordifolia dapat meningkatkan imunitas sapi. Akar
Tinospora cordifolia dapat mengatasi ternak yang lemah (Phondani et al., 2010). Sahoo et al. (2001) menyatakan bahwa poli herbal yang mengandung Tinospora dapat meningkatkan performa ternak, daun berkasiat sebagai analgesik (Goel et al.,2014), serta dapat mengatasi penyakit kulit (Tariq et al., 2014).

Sembukan (Paederia foetida L.) dimanfaatkan petani untuk meningkatkan nafsu makan ternak, mengatasi kembung dan diare. Banyak peneliti telah membuktikan Sembukan (Paederia foetida L.) dapat digunakan untuk mengatasi gangguan saluran pencernaan seperti disentri, diare, cacingan (Borah et al., 2006., Afroz et al., 2006., Jamir et al., 1999., Roychoudhury et al., 1970., dan Chanda et al., 2015), menghambat motilitas intestinum (Afroz et al., 2006).

Tiga orang peternak mempergunakan daun Binahong untuk menyembuhkan luka, Binahong secara experimental dapat menyembuhkan luka pada tikus yang diabetes (diabetic rats) (Kintoko dan Desmayati, 2016), mampu menurunkan kadar kolesterol dan trigliserida pada tikus Wistar namun tidak berpengaruh terhadap kadar HDL (Lestari et al., 2015), Binahong 
juga dapat dipergunakan sebagai anti bakteria (Maharani et al., 2018)

Temulawak dipergunakan oleh peternak untuk meningkatkan nafsu makan, pencegahan penyakit, dan untuk penyakit cacingan. Temulawak dilaporkan memiliki aktivitas sebagai anti hepatitis, diabetes, rheumatism, anticancer, antihipertensi, gangguan pada jantung, anti oksidan, anti jamur dan lainnya (Salleh et al., 2016). Sirih dipergunakan oleh peternak untuk mengobati penyakit mata, kandungan minyak esensial pada sirih bisa berfungsi sebagai anti radang, anti bakteri, gangguan pada sistem urogenital, kulit, perut dan lain-lain (Salehi et al., 2019). Untuk meningkatkan nafsu makan dan stamina peternak juga ada yang memanfaatkan daun pisang. Hasil penelitian Kappel et al. (2013) ekstrak daun pisang dapat meningkatkan metabolisme karbohidrat, dan sangat potensial sebagai anti-diabetes. Secara in vitro daun pisang bisa sebagai antibakteria (Sahaa et al., 2013). Salah satu peternak responden menggunakan kopi untuk mengatasi kembung, peternak di Swedia menggunakan kopi untuk mengatasi gangguan pencernaan dan disfungsi metabolik pada ternak (Scmid et al., 2012). Ponepal et al. (1996) melapotkan pemberian extrak kopi secara sub cutan dapat mempercepat kesembuhan $30 \%$ pedet yang menderita diare.

Jengkol dipergunakan untuk mengatasi kembung, sejauh ini belum ada bukti ilmiah untuk hal ini, tetapi Charungchitrak et al. (2011) menyatakan bahwa biji Archidendron jiringa menunjukkan aktivitas sebagai antijamur. Peternak juga menggunakan air kelapa untuk mengatasi kembung, Deb Mandal and Mandal (2011) menyatakan bahwa air kelapa kaya akan elektrolit sehingga bisa dipergunakan sebagai sumber elektrolit tubuh, dan anti dota. Hasil penelitian juga menunjukkan bahwa beberapa herbal seperti kunyit, jahe dan asam jawa tidak mampu mengurangi penyakit infeksi pada sapi khususnya Jembrana.

\section{KESIMPULAN}

Tercatat 33 medicinal herbs dipakai oleh petani peternak. Medicinal herbs dari famili Zingiberaceae khususnya Curcuma longa Linn dan Curcuma domestica merupakan medicinal herbs yang paling banyak dipergunakan untuk meningkatkan nafsu makan, mencegah penyakit, bloat, infestasi parasit internal, dan luka. Pemberian secara per os merupakan metode yang paling banyak dipergunakan diikuti dengan cara topikal. Pemberian herbal tidak bisa mengatasi penyakit infeksi seperti Jembrana. Diperlukan sosialisasi tentang manfaat hebal kepada peternak secara lebih luas, mengingat beberapa herbal terbukti secara ilmiah memiliki kasiat yang lebih banyak dan beragam dibanding dengan pengetahuan peternak.

\section{UCAPAN TERIMAKASIH}

Terimakasih pada DPRM dan pimpinan Universitas Bengkulu, penelitian ini merupakan bagian dari Penelitian Strategis Nasional 2019 dengan nomor kontrak 758/UN 30. 15/LT/2019, terimakasih juga kepada peternak responden.

\section{DAFTAR PUSTAKA}

Aghsaghali, A.M. 2012. Importance of medical herbs in animal feeding: A review. Annals of Biological Research. 3 (2): 918-923.

Afroz, S., M. Alamgir, M. T. H. Khan, S. Jabbar, N. Nahar, and M. S. K. Choudhuri. 2006. Antidiarrhoeal activity of the ethanol extract of Paederia foetida Linn. (Rubiaceae). Journal of Ethnopharmacology. 105 (1-2):125-130.

Al-Azazi, A, S.H., F.A Tayeb, T.A Baraka and A. M. Khalaf. 2018. Effect of Ginger Powder (Zingiber officinale) on Selected Rumen and Blood Serum Constituents In Sheep. Indian Journal of Applied $\begin{array}{llll}\text { Research. } & 8 & \text { (4): }\end{array}$ 
Ameen S.A., S.O. Adedeji , L.O. Ojedapo, T. Salihu and C.O. Fabusuyi. 2010. Anthelmintic Potency of Pawpaw (Carica papaya) Seeds in West African Dwarf (WAD) Sheep. Global Veterinaria 5 (1): 30-34.

Ammon, H. and M.A Wahl. 1992. Pharmacology of Curcuma longa. Planta Med. 1: 57: 17

Anwar, F., S. Latif, M. Mushraf, and A.H Gilani. 2005. Moringa oleifera: A Food Plant with Multiple Medicinal Uses. Phytotherapy Research. 21 (1): 17-25. DOI:10.1002/ptr.2023.

Astuti, S., M., M. Sakinah, R. Andayani and A. Risch. 2011. Determination of saponin compoud from Anredera cordifolia (Ten) Steenis Plant (Binahong) to potential treatment for several diseases. Journal of Agricultural Science 3 (4): 224- 232. DOI: $10.5539 /$ jas.v3n4p224.

Bath, N. 2015. Herbs and herbal supplements, A novel Nutritional approcah in Animal Nutrition. Iranian Journal of Applied Animal Science 5(3): 497-516.

Begum, S., S.I. Hassan, S.N. Ali and B.S. Siddiqui. 2004. Chemical constituents from the leaves of Psidium guajava. Journal Natural Product Research. 18 (2): 135-140.

Borah, P., K., P. Gogoi, A. Phukan, and J. Mahanta. 2006. Traditional medicine in the treatment of gastrointestinal diseases in Upper Assam. Indian Journal of Traditional Knowledge. 5: 510-512.

Brewster, J. L. 1994. Onions and other vegetable alliums. $\mathrm{CAB}$ International, Wallingford, 236.

Bunawan, H., L. Dusik, S.N. Bunawan and N.M. Amin. 2013. Botany, Traditional Uses, Phytochemistry and Pharmacology of Archidendron jiringa. Global Journal of Pharmacology. 7 (4): 474-478.

Cervantes-Valencia, M. E., Y. Alcala-Canto, A. Z. M. Salem, A E. Kholif, A. M. Ducoing-Watty, M. J. Bernad-Bernad and C. Gutiérrez-Olvera. 2015. Influence of Curcumin (Curcuma longa) as a Natural Anticoccidial Alternative in Adult Rabbits: First Results, Italian Journal of Animal Science. 14 (3): 298304.

Chanda, S., L Deb, R. K. Tiwari, K. Singh, K. and S. Ahmad. 2015. Gastroprotective mechanism of Paederia foetida Linn. (Rubiaceae)--a popular edible plant used by the tribal community of North-East India. BMC Complementary and Alternative Medicine, 15, 304. doi:10.1186/s12906-015-0831-0.

Charungchitrak, S., A. Petsom P. Sangvanich and A. Karnchanatat. 2011. Antifungal and antibacterial activities of lectin from the seeds of Archidendron jiringa Nielsen. Food Chemistry. 126 (3): 1025-1032.

Dalimartha, S. 2009. Atlas Tumbuhan Indonesia. Jilid 6. Pustaka Bunda. Jakarta.

DebMandal, M. and S. Mandal. 2011. Coconut (Cocos nucifera L.: Arecaceae): In health promotion and disease prevention. Asian Pacific Journal of Tropical Medicine. 4 (3): 241-247.

Divya, B. J., B. Suman, L. L Kumar, M. Venkataswamy, B. Eswari and K. Thyagaraju. 2017. The Role of Allium sativum (Garlic) In Various Diseases And Its Health Benefits: A Comprehensive Review. Int'1 Journal of Advanced Research. $5 . \quad 2320-5407$. 10.21474/IJAR01/5094.

Doughari, J.H. 2006. Antimicrobial Activity of Tamarindus indica Linn. Tropical Journal of Pharmaceutical Research. 5 (2): 597-603.

Frita, Y. N., H. L. Chang, M. J. Lin and E. Widodo. 2016. Effect of Curcuma domestica Stock Solution on Layer Performance, Egg Quality, and Antioxidant Activity. The 7 th International Seminar on Tropical Animal Production Contribution of Livestock Production on Food Sovereignty in Tropical Countries. September 12-14. Yogyakarta, Indonesia. 
Garmana, A. N., E.Y. Sukandar and I. Fidrianny. 2014. Activity of several plant extract against drug-sensitive and drug resistant microbes. Intenational Seminar on Natural Product Medicines, Procedia Chemistry (13): 164-169.

Goel, B., N. Pathak, D. K., Nim, S. K Singh, R. K., Dixit, and R. Chaurasia. 2014. Clinical evaluation of analgesic activity of guduchi (Tinospora cordifolia) using animal model. Journal of Clinical and Diagnostic Research 8 (8), HC01-HC4. doi:10.7860/JCDR/2014/9207.4671

Gupta, A. K., C. Sannat, R. Agrawal and S. D. Hirpurkar. 2016. Effect of Feeding of Tinospora cordifolia on Immune Response in Cattle. Journal of Animal Research: 6 (4): 579-584.

Sirat, H. M., S. Jamil and J. Hussain. 1998. Essential Oil of Curcuma aeruginosa Roxb. from Malaysia. Journal of Essential Oil Research. 10 (4):453-458.

Hatcher, H., R. Planalp, J. Cho, F. M.Torti, and S.V.Torti. 2008. Curcumin: from ancient medicine to current clinical trials. Cell Mol Life Sci. 8:65(11):1631-1652. doi:10.1007/s00018-008-7452-4

Jabbar, A., M. A. Raza, Z . Iqba., and M. N. Khan. 2006. An inventory of the ethnobotanicals used as anthelmintics in the southern Punjab (Pakistan). Journal of Ethnopharmacology. 108: 152-154.

Jamir, T.T., H. K. Sharma, and A. K. Dolui . 1999. Folklore medicinal plants of Nagaland, India. Fitoterapia. 70: 395-401.

Jantan, I and F. C. Saputri. 2012. Correlation between Chemical Composition of Curcuma domestica and Curcuma xanthorrhiza and Their Antioxidant Effect on Human Low-Density Lipoprotein Oxidation. Evidence-Based Complementary and Alternative Medicine. 1-10.

Joshi, M, K., S. Gaonkar, S. Mangoankar, and S. Satarkar. 2012. Pharmacological investigation of Areca catechu extracts for evaluation of learning, memory and behavior in rats. International Current Pharmaceutical Journal. 1 (6): 128-132.

Kappel, V, D., L. H. Cazarolli, D. F. Pereira, B. G. Postal, F. A. Madaglio, Z. A. Buss, F. H. Reginatto, and F. R. M. B. Silva. Beneficial effects of banana leaves (Musa paradisiaca) on glucose homeostasis: multiple sites of action. Revista Brasileira de Farmacognosia. 23 (4) : 706-715.

Khanzada, S. K., W. Shaikh, T. G. Sofia, K. Kazi, K. Usmanghani, A. Kabir and T. H. Sheerazi. 2008. Chemical constituents of Tamarindus indica. Medicinal plant in Sindh. Pakistan Journal Botany. 40 (6): 2553-2559.

Kintoko, K., and A. Desmayati. 2016. The effectivity of ethanolic extract of binahong leaves (Anredera cordifolia (tenore) steen) gel in the management of diabetic wound healing in aloxaninduced rat models. Jurnal Kedokteran dan Kesehatan Indonesia. 7 (5): 227-236.

Kumar, K. P. S., D. Bhowmik, B. Chiranjib, and P. Tiwari. 2010. Allium cepa: A traditional medicinal herb and its health benefits. Journal of Chemical and Pharmaceutical Research. 2 (1): 283-291.

Kurniawati, A., Widodo, W.T. Artama and L. M. Yusiati. 2018. Study of Local Herb Potency as Rumen Modifier: The Effect of Red Ginger (Zingiber officinale Var.Rubrum) on Parameters of Ruminal Fermentation In vitro. IOP Conference Series: Earth and Environmental Science.

Lestari, D., E. Y. Sukandar and I. Fidrianny. 2015. Anredera cordifolia leaves extract as Antihyperlipidemia and Endothelial Fat Content Reducer in Male Wistar Rat. International Journal of Pharmaceutical and Clinical Research 7(6): 435-439.

Maharani, E. S., R. Puspitawati, and H. A. Gunawan. 2018. Antibacterial effect of binahong (Anredera cordifolia (Ten.) Steenis leaf infusion against black pigmented bacteria. IOP Conf. Series: Journal of Physics: Conf. 
Menezes, A. P. P., S. C. Trevisan, S. M. Barbalho and E. L. Guiguer. 2016. Tamarindus indica L. A plant with multiple medicinal purposes. Journal of Pharmacognosy and Phytochemistry. 5 (3): 50-54.

Oche, O., A, Rosemary, O. John, E. Chidi, S. M. Rebecca, and U. A. Vincent. 2017. Chemical Constituents and Nutrient Composition of Carica papaya and Vernonia amygdalina Leaf. Journal of Complementary and Alternative Medical Research 2 (1): 1-8.

Okoli, R. I., O. Aigbe., J. O. Ohaju-Obodo, and J. K. Mensah. 2007. Medicinal Herbs Used for Managing Some Common Ailments among Esan People of Edo State, Nigeria. Pakistan Journal of Nutrition. 6 (5): 490496.

Peng, W., Yu-JieLiu, NaWu, TaoSun, XiaoYanHe, Yong-Xiang Gao, and ChunJieWu. 2015. Areca catechu L. (Arecaceae): A review of its traditional uses, botany, phytochemistry, pharmacology and toxicology. Journal of Ethnopharmacology 164:340-356.

Phondani, P.C., R. K. Maikhuri and C. P. Kala. 2010. Ethnoveterinary uses of medicinal lants among traditional herbal healers in alaknanda catchment of Uttarakhand, India. African Journal Traditional Complementary and Alternative Medicines 7 (3):195-206.

Ponepal, V., U.Spielberger,G. Riedel-Caspari, and F.W. Schmid. 1996. Use of a Coffea arabica tosta extract for the prevention and therapy of polyfactorial in- fectious diseases in newborn calves. Dtsch Tierarztl Wochenschr. 103:390394.

Pratiwi, N. P. R. K. dan I.W. Muderawan. 2016. Analisis Kandungan Kimia Ekstrak Daun Sirih Hijau (Piper betle) Dengan GCMS. Prosiding Seminar Nasional MIPA Undiksha 9 Oktober 2016, Bali.

Roychoudhury, G. K., A. K. Chakrabarty and B. Dutta.1970. A preliminary observation on the effects of Paederia foetida on gastro- intestinal helminths in bovines. The Indian Veterinary Journal. 47: 767-769.

Sahaa, R. K., S. Acharyaa, S. Shovon, and P. Royb. 2013. Medicinal activities of the leaves of Musa sapientum var. sylvesteris in vitro. Asian Pacific Journal of Tropical Biomedicine 3 (6) : 476-482. doi:10.1016/S2221-1691(13)60099-4.

Sahoo, N., N.C. Behura and J. Mishra. 2001. Effects of Immu-21 on certain blood biochemicals, milk, colostrum, body weight gain and livability in goats. Phytomedica. 2 (1 \& 2): 69-76.

Salehi, B., Z. Amiruddin, Zakaria, R. Gyawali, S. A. Ibrahim, J. Rajkovic, Z. Khan Shinwari, T. Khan, J. SharifiRad, A. Ozleyen, E. Turkdonmez, M. Valussi, T. B. Tumer, L. M. Fidalgo, M. Martorell, and W. N. Setzer. 2019. Piper Species: A Comprehensive Review on Their Phytochemistry, Biological Activities and Applications. Molecules. 24 (7): 1364.

Salleh, N. A. M., S. Ismail, and M. R. Ab Halim. 2016. Effects of Curcuma xanthorrhiza Extracts and Their Constituents on Phase II Drugmetabolizing Enzymes Activity. Pharmacognosy Research. 8 (4): 309315.

Schmid, K., S. Ivemeyer, C. Vofl, B. Meier, M. Hamburger and M. Walkenhorst. 2012. Traditional Use of Herbal Remepelets in Livestock by Farmers in 3 Swiss Cantons (Aargau, Zurich, Schaffhausen) Forchende Komplementarmedizin. 19: 125-136.

Shao, M., Y. Wang, Y.Q. Jian, X.G. Sun, X.J. Huang, X.Q. Zhang and W.C Ye. 2014. Chemical constituents of leaves of Psidium guajava. Zhongguo Zhong Yao Za Zhi. 39 (6):1024-1029.

Shaswat, O., R. Adarsha, R. Alokesh and R. Sudipta. 2018. Extraction of Total Phenolics, Flavonoids and Tannins from Paederia foetida L. Leaves and their Relation with Antioxidant Activity. Pharmacognosy Journal 10 (3): 541-547. 
Simoh, S. and A. Zainal. 2015. Chemical profiling of Curcuma aeruginosa Roxb. rhizome using different techniques of solvent extraction.Asian Pasific Journal of Tropical Biomedicine. 5 (5): 412-417.

Singh, S., S.C. Pandey, S. Srivastava, V.S. Gupta, B. Patro, and A.C. Ghosh. 2003. Educational Forum Chemistry And Medicinal Properties of Tinospora cordifolia (Guduchi). Indian Journal of Pharmacology 35: 83-91

Sukari, A., S. M. Saa, N. Lajis, M. Rahmani, R. Muse ,U. K. Yusuf and S. Riyanto. 2007. Chemical Constituents and Bioactivity of Curcuma aeruginosa Roxb. Natural Product Sciences 13 (3). 175-179.

Suteky, T. and Dwatmadji. 2011. Anthelmentic Activity of Melastoma Malabatricum Extract on Haemonchus Contortus In Vitro. Asian Journal of Pharmaceutical and Clinical Research. Supplement 1: 6871.

Suteky, T. and Dwatmadji. 2016. Effect of Melastoma malabatricum and Feed Supplementation on Local Goat Infected with Haemonchus contortus in Ruminant-Oil Palm Integrated System. Journal of Agricultural Technology 12 (7.1):1565-1574

Suteky, T., A. Sudaryano, E. Widiyanti, T. E. Suharto, A. Supriyadi dan Kancono. 1998. Inventarisasi tumbuhan obat yang mengandung alkaloid di Taman Nasional Kerinci Seblat. Laporan Penelitian KEHATI.

Suteky, T., Dwatmadji, and E. Soetrisno. 2014. The potential use of Melastoma malabatricum extract as natural anthelmintic against Haemonchus contortus of goat for small farmer in Bengkulu. The 5th International Seminar Regional Network on Poverty Eradication. Bank University Ho Chi Minh City, Vietnam 22-14 October 2014.
Suteky, T., Dwatmadji, I. Katsiri and Mida. 2016. Present Status of Livestock Disease in the Coastal Region South Bengkulu Indonesia. Proceeding International Seminar on Sustainable Utilization of Coastal Resources in Tropical Zone 19-20 October, 2016, Bengkulu, Indonesia.

Tariq, A., S Mussarat, M. Adnan, M. Naser, Abd Elsalam, R. Ullah, and A. Latif Khan. 2014. Ethnoveterinary Study of Medicinal Plants in a Tribal Society of Sulaiman Range Akash. 1-10. http://dx.doi.org/10.1155/2014/127526 .

Ullah, H., S. H. Abbas Raza, M. Saeed, M. Sun Chao, M. Arain, A. R. N. Soomro, I. H. Abbasi, and R. Gan Lu. 2015. Documentation of Ethno Veterinary Practices in District Charsadda, Khyberpakhtunkhwa. International Journal of Livestock Research. 5 (10): 47-63.

Wang, L., Y. Jiang, T. Han, C. Zheng and L. Qin. 2014. A Phytochemical, Pharmacological and Clinical Profile of Paederia foetida and $P$. Scandens Natural Product Communications. 9 (6): 879-886.

WHO. 2008. Traditional Medicine. Fact Sheet No 134.

http://www.who.int/mediacentre/factsheets /2003/fs134/en/, accessed 10 Mei 2019.

WHO. 2013. WHO Traditional Medicine Strategy 2014-2023

http://www.who.int/medicines/publications /traditional/trm_strategy14_23/en/ accessed 14 Mei 2019.

Yong, W. J. W. H., L. Ge, Y. F. Ng, and S. N. Tan. 2009. The chemical composition and biological properties of coconut (Cocos nucifera L). Molecules. 14:5144-5164.

Zadeh, Z. B. and N. M. Kor. 2014. Physiological and pharmaceutical effects of Ginger (Zingiber officinale Roscoe) as a valuable medicinal plant. European Journal of Experimental Biology, 2014. 4 (1):87-90. 